ORIENTAL JOURNAL OF
ISSN: 0974-6471
June 2017,
COMPUTER SCIENCE \& TECHNOLOGY
$\begin{gathered}\text { An International Open Free Access, Peer Reviewed Research Journal } \\ \text { Published By: Oriental Scientific Publishing Co., India. }\end{gathered}$
www.computerscijournal.org

\title{
Website Design of Indian Central Universities: Issues and Challenges
}

\author{
MUDASIR M KIRMANI \\ Computer Science Sher-e-Kashmir University of Agricultural \\ Sciences \& Technology of Kashmir Srinagar, J\&K, India \\ Corresponding author Email: mmkirmani@gmail.com
}

http://dx.doi.org/10.13005/ojcst/10.02.39

(Received: May 19, 2017; Accepted: May 25, 2017)

\begin{abstract}
World has shrunk into logically small e-village where everyone can communicate with every other person with great ease via both audio and visual media. The existence of being a global village has only been possible with interconnected communication links connecting users from geographically distant areas. The most predominant media for achieving this is with the help of well developed website. Educational institutions play vital role in reshaping any nation by imbibing quality attributes in culture, civilization and modernization. The information available on websites of educational institutions has become very important for prospective students and at present most of the universities are completing the process of admissions online with websites as mediators. Therefore, the need of the hour is to have updated and informative websites with ease of access. A key feature of the ongoing growth of Worldwide Web over the past decade has seen proliferation of web portals and mobile applications that focus on supporting education. The main aim of this research work is to study websites of central universities established post 2004 to explore their quality parameters and to get an insight into the challenges faced by prospective users. The research work recommends a common design framework for all central universities in order to help prospective users with understanding and usage of central universities websites.
\end{abstract}

Keywords: Central university, Websites design, GUI guidelines, Website design standards, Higher education, Load time.

\section{INTRODUCTION}

The indigenous and indispensable role of Information and Communication Technology (ICT) across the vertical and horizontal horizons has increased. The demand, dependence and availability of web-based information has become a lifeline for many organizations to survive.
The information presented over the web must be reliable, fast, accessible, understandable, and beneficial for the prospective users. The globalization of present era and varying trends in information age has made a common person fully dependent on information available online on websites or portals. The information presented, published and made available to common masses 
needs to be dealt with caution Apart from ensuring quality of the content issues related to security and reliability need to be addressed keeping in mind the present scenario e-connectivity across the globe. The world wide web (www) has now dramatically shifted the way a common man used to look at the educational institutions and has resulted in most of the educational institutions having their presence on online word with the help of websites. Application of ICT and web hosting in an academic environment has increased dramatically in the recent decade.

At present all the Central, State, Deemed and PrivateUniversities are required to publish information related to their respective institutions of repute available and accessible over internet. The main aim of an educational institution is not to make the content available on internet rather the objective is to reach to masses with the help of internet connectivity. The need to a have a reliable, effective and attractive web presence is increasing as online technology is becoming an important part educational institutions in general and society in particular ${ }^{1}$.

The higher educational institutions play a vital role in the development of a society while higher education websites play a vital role in bridging the gap between the institution and stakeholders ${ }^{2}$. Institutions of higher learning websites provide a platform for efficient communication and access to public information. These websites are a useful tool to enhance transparency and data availability as they enable different stakeholders to interact with different institution of higher learning [3]. Web based platforms are only available media wherein instant publication of information is viable to reach out global masses instantly.

There are many interest groups who are visitors to these websites in general and higher educational institutional websites in particular. As far as the academics of any higher educational institute in concerned there is different pragmatic aspects for which a student or any other academician is main visitor. A prospective student or a stake holder explores the website of a university or any institution of higher learning to get information about university's vision, mission and other academic or research related information. The information available on university websites is not only useful for internal users rather the information is very important for external users as well ${ }^{2,4}$. The internal user like a student, faculty or employee who are physically well and those are visually impaired can get information about their daily activities, proformas, university news and other miscellaneous information ${ }^{4}$. Similarly, an external user can get detailed information about the university, courses available, research domains, award \& achievements, upcoming events and other related information from the university website the design of the website should be so pleasing that the visitor may attracted by the way the information is being presented with ease of menu item identifiers and search filters provided within the container webpage $e^{5,6,7}$. Hence each individual website of any organizations acts like the physical existence in virtual reality. There is no doubt that there are certain educational institutions whom are providing very quality and most valuable education have no physical existence but yes they do abode on internet with website $U R L$ as only interface to reach globally to different interest groups.

The University Grants Commission (UGC) of India is a statutory body set up by the Indian Union government in accordance to the UGC Act 1956 under Ministry of Human Resource Development ${ }^{8}$, and is charged with coordination, determination and maintenance of standards in higher educational institutions. It provides recognition to universities in India, and disburses funds to such recognized universities and colleges.

The higher educational sector at present has 45 Central Universities, 318 State Universities, 185 State Private universities, 129 Deemed to be Universities, 51 Institutions of National Importance (established under Acts of Parliament) under MHRD (IITs - 16, NITs - 30 and IISERs - 5) and four Institutions (established under various State legislations) ${ }^{9}$. At present, the main categories of University/University-level Institutions are:- Central Universities, State Universities, Deemed-to-be Universities and University-level institutions. These are described as follows ${ }^{10,11}$ : 


\section{Central University}

A university established or incorporated by a Central Act.

\section{State University}

A university established or incorporated by a Provincial Act or by a State Act.

\section{Institution of National Importance}

An Institution established by Act of Parliament and declared as Institution of National Importance. Institution under State Legislature Act

\section{Deemed-to-be University}

An Institution Deemed to be University, commonly known as Deemed University, refers to a high-performing institution, which has been so declared by Central Government under Section 3 of the University Grants Commission (UGC) Act, 1956.

\section{Private University}

A university established through a State/ Central Act by a sponsoring body viz. A Society registered under the Societies Registration Act 1860 , or any other corresponding law for the time being in force in a State or a Public Trust or a Company registered under Section 25 of the Companies Act, 1956.

\section{An Institution established or incorporated by a State Legislature Act.}

All the central universities are established and funded by the Central Government of India. In general, universities in India are recognized by the University Grants Commission (UGC), which draws its power from the University Grants Commission Act, $1956^{8}$. In addition, central universities are covered by the Central Universities Act, 2009, which regulates their purpose, powers governance etc. However, it would not be surprising to see different central universities having different nomenclature, different component management and varying content flow and organization on their respective websites while providing information to different internal and external users/stakeholders. Keeping in mind the similarities in working, governing, managing, monitoring and controlling of central universities, a similar nomenclature, pattern, and design and interference framework of website for all central universities can work as a helping hand in enhancing the information penetration to the masses. It will ease of access among the interest groups to make walk through and walk back among different WebPages of websites to locate access and retrieve information content.

As per the data available on UGC website the existing list of central universities is given table 1 below $^{9}$

The need of the hour is to have similar website rather common design framework/ template or pattern for website development and publishing for all institutes of higher learning in general and Indian Central Universities in particular. The similar fashion of presenting the contents in specified and specialized parts provides the visitor with ease in access and efficient content localization with these commonalities in development of websites in mind, the guidelines for the development of the websites in general and customized webpage's in particular clearly describe the following:

- what elements make up the common website template

- what elements are mandatory for every website

- what elements can be adapted for individual websites

\section{Page elements overview}

The main components of a website of any organization in general and central university in particular and their corresponding position on the web portals is shown in figure 1 below.

The main complements which are shown in figure 1 above are Masthead, Navigation, page content, page borders and footer. All the components has their respective set of attributes associated with them which play an pivotal role in effectiveness of a website design.

\section{Importance of common template in websites of central universities}

Now-a-days the main source of communication rather speaking nodes for any higher learning educational institute especially central university are there websites, so to make this communication more effective all the components 
Table 1: Indian Central Universities in 2016

\section{S. No. Name of Central University}

$1 \quad$ Rajiv Gandhi

University, Itanagar

2 Assam University,

Silchar-788011

3 Tezpur University,

Tezpur-784028

4 Central University of

South Bihar, Patna-1.

5 Mahatma Gandhi Central

University, North Bihar

6 Nalanda University, Rajgir,

Dt. Nalanda, Bihar

7 Guru Ghasidas Vishwavidyalaya,

Bilaspur-495009

8 Central University of

Gujarat, Gandhinagar-382007

9 Central University of Haryana,

10 Central University of Himachal Pradesh

11 Central University of Jammu \&

Kashmir, Saderbal, Srinagar-190006

12 Central University of Jammu, Jammu.

13 Central University of Jharkahnd, Ranchi-9,

Central University of Karnataka, Gulbarga-585106

Central University of Kerala, Trivandrum-695017,

Dr. Harisingh Gour Vishwavidyalaya, Sagar-470003.

The Indira Gandhi National Tribal

University, Amarkantak, Madhya Pradesh.

18 Mahatma Gandhi Antarrashtriya Hindi

Vishwavidyalaya, Wardha.

19 Central Agricultural University,

Imphal-795004.

20 Manipur University, Imphal-795003.

$21 \quad$ North Eastern Hill University, Shillong-793022.

22 Mizoram University, Aizawal-796012.

23 Nagaland University, Nagaland-797001.

24 Central University of Orissa, Camp Office

28/6, Betin Pal Road Extn. PO

Kalighat, Kolkata-700026.

Central University of Punjab,

PO Box 55, Bathinda, Punjab-151001.

Central University of Rajasthan, Main

Building, Secretariat, Jaipur, Rajasthan-302005

27 Sikkim University, Gangtok

Central University of Tamil Nadu, Tiruvarur-610001, Tamil Nadu.

Indian Maritime University, Chennai-600119.

Hyderabad University, Hyderabad-500046.
Year Established

1985(Central w.e.f. 2007)

1994

1994

2009

2016

2010

1983(Central w.e.f. 2009)

2009

2009

2009

2009

2009

2009

2009

1946(Central w.e.f. 2009)

2008

1997

1993

1980

1973

2000

1994

2009

2009

2009

2007

2009

2008

1974 
31 Maulana Azad National Urdu University, Hyderabad-500032.

1998

32 The English and foreign Languages University, Hyderabad-500007.

33 Tripura University, Agartala-799130.

1973(Central w.e.f. 2007)

34 Aligarh Muslim University, Aligarh-202002.

35 University of Allahabad, Allahabad-211002

987

Babasaheb Bhimrao Ambedkar University, Lucknow-226025.

Banaras Hindu University, Varanasi-221005.

1887

Rajiv Gandhi National Aviation Universrity, Raibareli.

1996

1916

39

Hemwati Nandan Bahuguna Garhwal University, Srinagar-246174 197

40 Vishwa Bharati University, Shantiniketan-731235.

1973(Central

Delhi University, Delhi-110007

w.e.f. 2009)

Indira Gandhi National Open University, New Delhi-110068.

1951

1922

Jamia Millia Islamia University, New Delhi-110025. 1988

Jawaharlal Nehru University, New Delhi-110067. 1969

South Asian University, New Delhi-110067. 2010

Pondicherry University, Pondicherry-605014.

1985

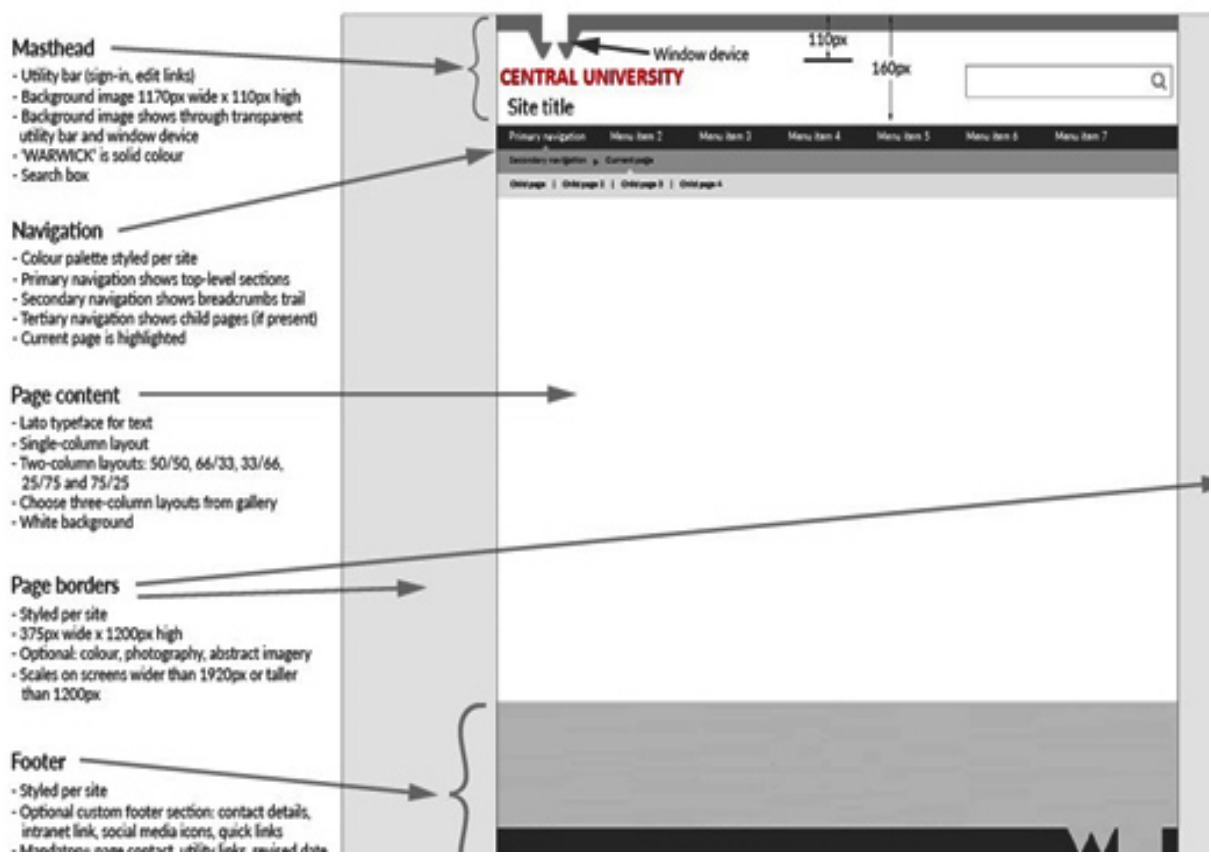

Fig. 1: The common elements and their place on generalized webpage of website

on website needs proper consensus and more pragmatic approach before publishing the content on the website on internet. The websites need a great attention in terms of design, development and review of content before publishing the same. The website must be designed keeping in mind the interest of the university which are primarily the sources of presenting their objectives to the end-user in general and those interested in seeking information in particular $2,3,4,7,13$. All the components which are plugged into the different web pages of a website needs to have unambiguous flow in its constituent components so that the exact information can be located and then retrieved in effectively and efficiently ${ }^{14,15}$. 
Table 2: List of basic required attributes of an educational institute website

\section{External User: (prospective student/ faculty or parents)}

Prospects;

Courses offered;

Mission \& Vision of the university;

Faculty details and contact information;

Facilities available;

Scholarships/fellowships/financial aids;

Placement record;

Contact (city information, weather, transportation, directions, contact and website ); Residential facilities (Hostel Information); Library (online resources and catalogue); Alumni; Job openings;

University Acts and Statutes;

Transparency Portal;

Faculty research information;

Information about Support services

(Medical, transportation, residence, counselling, schools, child care etc);

Faculty contact information;

Online registration (UMS);

Student clubs;

Information about student organizations;

Various university standalone centres for excellence like Information and

communication centre etc.

Help, Disability Support, present on

Social networking.

Internal User: (student/employee/staff)

University News, Orders, Events,

Notifications, Calendar;

Employee corner;

Transparency Portal;

Library catalogue (issue and return of

books online):OPAC

Academic calendar with list of holidays,

Important dates;

Different activities of University;

Grievance redressal information system;

Facilities (infrastructure/sports/ etc);

Student academic records:

Feedback;

Important links (UGC, Anti-ragging, sexual

harassment, free resources, online study material, research information etc);

Common resources for both internal and external user:

Search facility (web search/ internal search);

How to reach; Sitemap;

Loading time;

Look \& feel;

Language (Engilish/Hindi/ one optional language)

Gallery; Frequent updation, Visitor Counter

RTI, Transparency Portal

Digital repository,

Any educational institute of higher learning in general and central university in particular can be more effective to reach global masses in highly effective and motivational way if following base points are considered while designing and development of websites.

- As most popular way of communication and disseminating in today's world is web based platform, so it is inevitable for any organization to have their complete information available as a speaking note in form of a website.

- Every institution of higher learning requires developing and publishing of all the basic and necessary information as WebPages and deploys the same on internet to reach the prospective audience.

- Nowadays websites play the most important and motivational role to forecast better prospects of any educational institute and also helps the academic institute to foster in administrative, academic and research activities.

- The websites of institutions of higher education also helps in ensuring quality of education in the institution apart from the development of online communities to discuss various issues on online notice boards and other related platforms.

- The website of higher education helps the regulatory authorities in monitoring and management of academic \& research activities to ensure quality of the education system.

Every central university needs to promote usage of online services for managing and monitoring of all activities within the university. The website of a university is a platform which can help in achieving this target. This will result 
in implementing governance within a university online also known as e-governance which results in bringing transparency in the system.

\section{Guidelines for designing websites for central universities}

The basic and fundamental approach for any organization to design web portals is to have deep analysis of their existence and role, more revelatory planning, and compact plan to function as roadmap for developing the practical framework for website. There can be number of procedures, strategies and different criterion for initiating the practical work ${ }^{16,17,18}$. Some of the popular directives are enlisted as under;

- Identification of target groups so as to find their requirements

- How important is the content for the identified audience?

- What level of security, scalability, availability, integrity and confidentiality could be imposed?

- Can university create the content or does the university need to outsource content creation?

- Does the university publish quality content?

- Are the targeted audience able to find the content they are looking for?

\section{Most popular and Basic design guidelines when content are ready are given below}

- The basic theme and purpose of any university

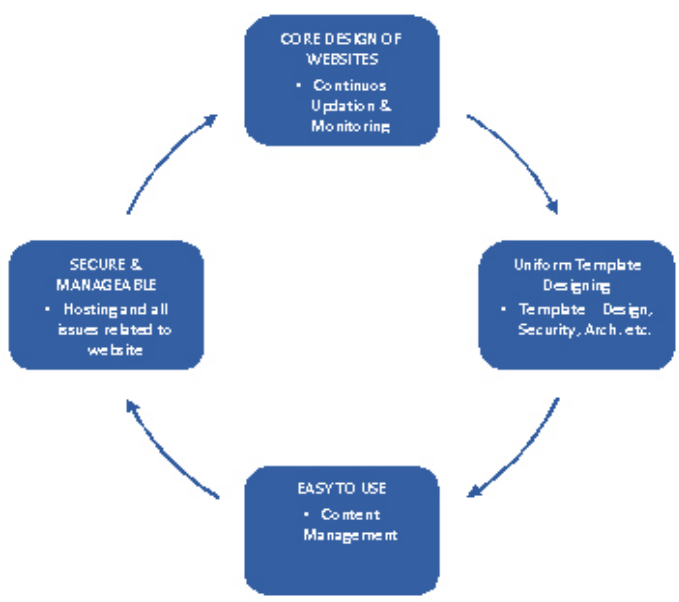

Fig. 2: Basic architecture for designing and development of educational websites should reflect from the very first webpage of any university. All the WebPages and images in line with text should speak the austerity and worthiness of University.

- The contents and navigation controls should let the visitor to traverse more and more across pages with motivational epitome.

- $\quad$ All the achievements, credits, Strengths and other contribution of the university should be glorified on university home page to make visitor to get addicted to visit and get more information. This can help in achieving the higher levels of publicity.

- Both semantics and syntax should ensure to increase content readability and understandably.

- $\quad$ All the important events, activities and other academic and administrative deadlines should be bold faced and more visible to capture visitors interest.

- Try to make your website precise, concise and simple.

\section{RESULTS AND DISCUSSIONS}

After deploying more pragmatic approach in collecting the basic similarities, features, quality parameters, content flow, interface design and other static \& dynamic attributes to improve the effectiveness of understandability for all stake holders. The list of attributes which needs to be included as the bare minimum requirement for desgning websited of an Institution of higher learning is given in table 2 .

In order to develop a template with uniform guidelines for developing websites for central universities the basic architecture is given in figure 1. The main aim and objective of carrying out this particular research was to analysis the websites of Indian Central Universities established post 2004 period to the challenges common visitor had to counter. The focus to given to identifying and to propose some common framework for all central universities to increase readability, accessibility, integrity, persistence and understandability. The main stress was provide to monitor four attributes in particular for all these post 2004 built universities that is Performance Grade, Load Time, Page Size and Requests by using pingdom tool online on 
Table 3: The detailed result of all central university established post 2004 period till 2016 against the parameters provided in the table

\begin{tabular}{|c|c|c|c|c|c|c|}
\hline S.No & $\begin{array}{l}\text { Name of Central } \\
\text { University }\end{array}$ & Website & Grade & Req. & $\begin{array}{l}\text { Load } \\
\text { Time }\end{array}$ & $\begin{array}{l}\text { Page } \\
\text { Size }\end{array}$ \\
\hline 1. & $\begin{array}{l}\text { Rajiv Gandhi University, } \\
\text { Itanagar }\end{array}$ & www.rgu.ac.in & 97 & 190 & $49.69 \mathrm{~s}$ & $40.9 \mathrm{MB}$ \\
\hline 2. & $\begin{array}{l}\text { Central University of } \\
\text { South Bihar, Patna-1. }\end{array}$ & https://www.cusb.ac.in & 82 & 92 & $9.52 \mathrm{~s}$ & $1.2 \mathrm{MB}$ \\
\hline 3. & $\begin{array}{l}\text { Mahatma Gandhi Central } \\
\text { University, North Bihar }\end{array}$ & www.mgcub.ac.in & 85 & 149 & $15.97 \mathrm{~s}$ & $7.4 \mathrm{MB}$ \\
\hline 4. & $\begin{array}{l}\text { Nalanda University, Rajgir, http } \\
\text { Dt. Nalanda, Bihar }\end{array}$ & os://www.nalandauniv.edu.in & in 94 & 102 & $3.94 \mathrm{~s}$ & $3.8 \mathrm{MB}$ \\
\hline 5. & $\begin{array}{c}\text { Guru Ghasidas } \\
\text { Vishwavidyalaya, Bilaspur }\end{array}$ & www.ggu.ac.in & 71 & 90 & $10.23 \mathrm{~s}$ & 4.3 MB \\
\hline 6. & Central University of Gujarat & www.cug.ac.in & 80 & 150 & $8.28 \mathrm{~s}$ & 4.5 MB \\
\hline 7. & Central University of Haryana, & www.cuh.ac.in & 76 & 21 & $4.51 \mathrm{~s}$ & 1.3 MB \\
\hline 8. & $\begin{array}{l}\text { Central University of } \\
\text { Himachal Pradesh }\end{array}$ & www.cuhimachal.ac.in & 81 & 56 & $4.79 \mathrm{~s}$ & $654.2 \mathrm{kB}$ \\
\hline 9. & $\begin{array}{l}\text { Central University of } \\
\text { Jammu \& Kashmir }\end{array}$ & ttps://www.cukashmir.ac.in & 67 & 147 & $7.42 \mathrm{~s}$ & 1.6 MB \\
\hline 10. & Central University of Jammu & www.cujammu.ac.in & 53 & 96 & $7.42 \mathrm{~s}$ & $2.5 \mathrm{MB}$ \\
\hline 11. & Central University of Jharkahnd & www.cuj.ac.in & 75 & 63 & $3.39 \mathrm{~s}$ & 1.9 MB \\
\hline 12. & $\begin{array}{l}\text { Central University of } \\
\text { Karnataka, Gulbarga- }\end{array}$ & www.cuk.ac.in & 72 & 77 & $1.15 \mathrm{~s}$ & $1.8 \mathrm{MB}$ \\
\hline 13. & Central University of Kerala & www.cukerala.ac.in & 100 & 18 & $2.46 \mathrm{~s}$ & $1.7 \mathrm{MB}$ \\
\hline 14. & $\begin{array}{c}\text { Dr. Harisingh Gour } \\
\text { Vishwavidyalaya, Sagar }\end{array}$ & www.dhsgsu.ac.in & 88 & 96 & $6.09 \mathrm{~s}$ & $3.8 \mathrm{MB}$ \\
\hline 15. & $\begin{array}{l}\text { The Indira Gandhi National } \\
\text { Tribal University, Amarkantak }\end{array}$ & igntu.ac.in & 65 & 263 & $15.97 \mathrm{~s}$ & $6.5 \mathrm{MB}$ \\
\hline 16. & Central University of Orissa & cuo.ac.in & 83 & 58 & $1.78 \mathrm{~s}$ & $2.3 \mathrm{MB}$ \\
\hline 17. & $\begin{array}{l}\text { Central University of Punjab, } \\
\text { PO Box 55, Bathinda }\end{array}$ & www.cup.ac.in & 78 & 6 & $4.63 \mathrm{~s}$ & $638.5 \mathrm{kB}$ \\
\hline 18. & Central University of Rajasthan & www.curaj.ac.in & 100 & 1 & $60.00 \mathrm{~s}$ & 514 kB \\
\hline 19. & Sikkim University, Gangtok & www.cus.ac.in & 76 & 67 & $9.55 \mathrm{~s}$ & 1.6 MB \\
\hline 20. & Central University of Tamil Nadu & cutn.ac.in & 87 & 90 & $7.46 \mathrm{~s}$ & 4.7 MB \\
\hline 21. Ir & ndian Maritime University, Chennai & www.imu.edu.in & 74 & 123 & $31.28 \mathrm{~s}$ & 7.5 MB \\
\hline 22. & $\begin{array}{l}\text { The English and foreign } \\
\text { Languages University, Hyderabad }\end{array}$ & www.efluniversity.ac.in & 66 & 61 & $18.09 \mathrm{~s}$ & $3.4 \mathrm{MB}$ \\
\hline 23. & $\begin{array}{l}\text { Rajiv Gandhi National } \\
\text { Aviation Universrity, Raibareli. }\end{array}$ & http://igrua.gov.in & 85 & 10 & $4.50 \mathrm{~s}$ & $464.8 \mathrm{kB}$ \\
\hline 24. & $\begin{array}{c}\text { Hemwati Nandan Bahuguna } \\
\text { Garhwal University }\end{array}$ & www.hnbgu.ac.in & 81 & 60 & $7.56 \mathrm{~s}$ & $793.4 \mathrm{kB}$ \\
\hline 25. $\varsigma$ & South Asian University, New Delhi & http://www.sau.int/ & 87 & 40 & $4.87 \mathrm{~s}$ & 1.4 MB \\
\hline
\end{tabular}


https://tools.pingdom.com/ website ${ }^{19}$. The results retrieved using the pingdom tool are given in table 3 below.

\section{CONCLUSION}

All the central universties established after 2004 have their own respective websites which are not similar in design which increases the burden of understability on the end user which results in demotivating prospective students. The need of the hour is to have common standards and design procedures for designing and publishing the content on a website of any central university. To overcome these challenges and issues it is recommended to design a common template in order to increase uniformity of the information available for prospective students across all central universities to begin with and the same can be further extended to all the institutions of higher learning. Students generally observe information available on university websites for facilitating them in decision making regarding admissions, results and other related activities as prospective students and enrolled students. The need of the hour is to establish a basic template which will be common to all the central universities which will result in uniformity in the information available on central universities websites across India. However, the design of central university template, website-homepages and website-pages need to be evaluated periodically using established yardstick which will help to improve website according to the end-user's requirements.

\section{REFERENCE}

1. B. Ramesh Babu, A. M. Naredra Kumar \& S. Gopalkrishnan: Credibility of University Websites in Tamil Nadu, DESIDOC Journal of Lib. \& Inf. Tech.,Vol.29No.3, May 09 pp 16-29.

2. Chandran, D. \& Ramesh Babu, B. Web resources: Access and evaluation. In Library resources and services in the digital era, edited by B. Ramesh Babu, et al. SRM University, Kattangulathur, 06. pp. 127- 35.

3. Chaparro, B. S., Shaikh, A. D., and Baker, J. R. ( 05). "Reading Online Text with a Poor Layout: Is Performance Worse?" Usability News, 7(1).

4. Jennifer Mankoff, Holly Fait, and Tu Tran, "Is your web page accessible? A comparative study of methods for assessing web page accessibility for the blind," In Proceedings of $\mathrm{CHI}$ 05pp. 41-50. (ACM DOI, pdf)

5. Katz, M. A., \& Byrne, M. D. ( 03). Effects of scent and breadth on use of sitespecific search on e-commerce Web sites. ACM Transactions on Computer-Human Interaction, 10, 198-2 . [PDF]

6. Lin, D. M. ( 04). Evaluating older adults_ retention in hypertext perusal: Impacts of presentation media as a function of text topology. Computers in Human Behavior,

\section{(4), 491-503.}

7. Mangala, Anil Hirwade. Websites of Indian universities: An evaluation. Himalaya Publishing House, Bombay, 05

8. "UGC Act-1956" (PDF). mhrd.gov.in/. Secretary, University Grants Commission. Retrieved 1 February 2016

9. Ozok, A.A., \& Salvendy, G., The effect of language inconsistency on performance and satisfaction in using the Web: Results from three experiments (2003). Behavior \& Information Technology 22 (3), 155-163.

10. B. Ramesh Babu , A.M. Narendra Kumar and S. Gopalakrishnan, Credibility of University Websites in Tamil Nadu, DESIDOC Journal of Library \& Information Technology, Vol. 29, No. 3, May 2009, pp. 16-28

11. http://mhrd.gov.in/university-and-highereducation. accessed on 5th August, 2016.

12. http://www.ugc.ac.in/oldpdf/Consolidated list of Central Universities as on 15.01.2016. pdf accessed on 5th August, 2016

13. Manzoor, M., \& Hussain, W. (2010). Usability Evaluation of Higher Education Websites. Science Series Data Report, Vol 4, No. 3;Mar 2012

14. Weiss, R., Knowlton, D., \& Morrison, G.R., Principles for using animation in computer- 
based instruction: Theoretical heuristics for effective design (2002). Computers in Human Behavior 18, 465-477

15. Parush, A., \& Yuviler-Gavish, N. (2004). Web navigation structures in cellular phones: The depth/breadth tradeoff issue. International Journal of Human-Computer Studies, 60(5-6), 753-770.
16. http://vpsc.uiowa.edu/brand/guidelines-web/. . accessed on 5th August, 2016

17. http://web.guidelines.gov.in/\#\&panel1-1. . accessed on 5th August, 2016

18. http://www.uwgb.edu/webdev/standards/ policy.asp. accessed on 5th August, 2016

19. https://tools.pingdom.com/. accessed on 5th August, 2016 